\title{
Improving Domestic Flour for Bread Making by Blending Extra Strong (ES) Flour
}

\author{
Yamauchi Hiroaki*1, NodA Takahiro*1, Matsuura-Endo Chie*1 \\ Nishio Zenta*1, Takata Kanenori*1, TABiKi Tadashi*1, SAito Katsuichi*1 \\ OdA Yuji*1, FunAtsuki Wakako*2 and IRIKI Norio*2
}
* 1 Department of Upland Agriculture Research, National Agricultural Research Center for Hokkaido Region (NARCH) Shinsei, Memuro, Hokkaido 082-0071
* 2 Department of Low-Temperature Sciences, National Agricultural Research Center for Hokkaido Region (NARCH) 1, Hitsujigaoka, Sapporo, Hokkaido $062-8555$

The bread-making quality of two domestic flours, Hokushin and Haruyutaka, blended with Victoria INTA, an ES flour, and Harunoakebono, domestic strong flour, was investigated. The baking quality of Hokushin, representative middle-strong flour in Hokkaido, and Haruyutaka, semi-strong flour with prehavest sprouting damage, which is unsuitable domestic flours for bread production, were both improved by blending with Victoria INTA. The results were as follows: (1) With an appropriate blend of ES flour, it was proven that domestic flours with poor bread making quality could be improved and given properties for bread making that are generally attributed to foreign hard flours. (2) The estimation of specific loaf volume of bread made from blends of the flours in this experiment was possible with the following multiple-regressive equation; $X_{1}=0.157 X_{2}+0.251 X_{3}+2.38\left(X_{1}\right.$ : specific loaf volume $(\mathrm{m} \ell / \mathrm{g}) ; \mathrm{X}_{2}$ : protein content of flour $(\%), \mathrm{X}_{3}$ : breaking force of dough $\left.(\mathrm{N})\right)$. (3) Through analysis by the use of this equation, it was proven that the improvements of bread making quality by blending poor domestic flours with ES flour were principally due to the progress of physical property of the dough, an increase in the breaking force of the dough.

(Received Mar. 3, 2003 ; Accepted May 19, 2003)

More than one million tons of flour is used to make bread every year in Japan, and the county is nearly dependent on the importation of wheat for bread production. Although a little wheat for bread making is produced in Japan, it is usually less than 10,000 tons, and much of it frequently has preharvest sprouting damage that degrades the bread making quality. Since, especially, the Japanese main variety of bread wheat, Haruyutaka, is semistrong wheat with the gluten that is somewhat weaker than strong wheat and it has weak characteristic for the preharvest sprouting damage, the bread making quality of commercial flour of Haruyutaka is rather lower than ordinary strong flour. In general, it is necessary that flour for bread making has strong gluten. However, the preharvest sprouting damage causes partial gluten decomposition by the endo-protease and the softening of gluten and physical property of dough is brought about as the result ${ }^{1}$, which seem to cause the drastic degradation of bread making quality of Haruyutaka having somewhat weak gluten. The majority of Japanese flours are middle-strong flour with medium strength of gluten that is used to make a Japanese wheat noodle, Udon. Because, Japanese have traditionally eaten the flour as Udon, and Japanese climate is not generally suitable for the cultivation of bread wheat. As the result, the high quality flour for bread is hardly produced in Japan, and it is difficult to make bread of good quality with domestic flours.

However, there is a strong consumer demand for bread made with domestic flour in Japan. Some advances are currently being made in breeding for bread wheat in Japan, which may ultimately lead to a better quality bread; however, it is expected to

* 1 E-mail : YAMAUCHI Hiroaki ; yamauti@affrc.go.jp, NODA Takahiro ; noda@affrc.go.jp, MATSUURA-ENDO Chie ; mechie@affrc.go.jp, NISHIO Zenta ; zenta@affrc.go.jp, TAKATA Kanenori ; takata@affrc.go.jp, TABIKI Tadashi ; tabiki@affrc.go.jp, SAITo Katsuichi ; k.saito@affrc.go.jp, ODA Yuji ; yujioda@affrc.go.jp

* 2 E-mail : FunATsuKI Wakako ; maruwaka@affrc.go.jp, IRIKI Norio ; iriki@affrc.go.jp 
take a long time before the bread is on the grocery store shelves. Therefore, to use these domestic flours for bread making effectively, we studied to improve the quality of the two domestic flours that have inferior baking quality to foreign flours. It has been proven partially that the poor qualities of domestic flour, such as specific loaf volume, crumb grain, bread aspect, and physical properties of the dough, can be improved by adding ES flour with a powerful gluten which is stronger than that of normal strong flour ${ }^{2 \sim 4)}$ and it becomes possible to use the domestic flours of low quality for bread making. In the meantime, scientists in other countries are evaluating the qualities of blended flours with ES flour. However, they are seeking improvements of flour quality in stability and simple baking qualities ${ }^{5), 6}$, and no research has been conducted regarding improvement mechanism in baking quality of blended flours with ES flour.

This study is a full investigation of improvements in the quality of bread made by blending domestic middle-strong flour and semi-strong flour with sprouting damage with ES flour. Furthermore, the study reports on the analysis of the improvements in the poor flours that were brought about by blending.

\section{Materials and Methods}

\section{Preparation of flours}

The wheat to prepare the flours in Tab.1, except for NO.1 Canada Western Red Spring Wheat ( 1 CW) and Hard Red Winter Wheat (HRW), were cultivated in a Memuro test field at the Hokkaido National Agricultural Research Center in 1998. The $1 \mathrm{CW}$ and HRW were obtained from the Food Agency in Japan. The grains, including $1 \mathrm{CW}$ and HRW, were milled at a Bühler test mill (Bühler Inc., Switzerland) and $60 \%$ extraction flours (flour) were obtained.

\section{2 . Properties of the flours}

The protein content of the flours was measured with an near infrared reflectance instrument (Inframatic 8120, PerCon, Co., Germany). The SDSsedimentation value (SV) of the flours was measured using a method of TAKATA et $a l^{7}$., which had been modified from a method of AXFORD et $a l^{8)}$. This method used $2.5 \mathrm{~g}$ of flour and swelling time was prolonged. The SDS-sedimentation volume was measured at 24 hours after the ordinary procedure of the SDS-sedimentation test. Swollen samples left for 24 hours in a cylinder filled with SDS-lactic acid reagent and water were inverted ten times. This was followed by reading the sedimentation volume at $40 \mathrm{~min}$ after inversion. The water absorption, development time, and weakness of dough were measured with a Farinograph (Blabender, Inc., Germany) according to the AACC method ${ }^{9)}$. The gelatinization characteristic of the flours with a Rapid Visco-Analyzer 3 D (RVA) (Newport Scientific Pty. Ltd., Australia), peak viscosity, was measured according to a method of WATANABE and SUzUKI ${ }^{10)}$.

\section{3 . Bread making and evaluation of the breads}

The bread making tests were carried out by notime method of following standard white bread formulation with the use of $1 \mathrm{CW}$ and $\mathrm{HRW}$ as controls : $200 \mathrm{~g}$ of flour, $10 \mathrm{~g}$ of sugar, $10 \mathrm{~g}$ of shortening, $4 \mathrm{~g}$ of salt, $4 \mathrm{~g}$ of yeast, 100ppm of ascorbic acid, and a suitable quantity of water ${ }^{11}$. Doughs were mixed to just beyond peak development, as indicated by the current curve, on the modified mixer described in following dough properties section. The dough was divided into two $100 \mathrm{~g}$ pieces, rounded, and rested for $20 \mathrm{~min}$ in a fermentation cabinet. The pieces were panned and proofed at $38^{\circ} \mathrm{C}$ for $70 \mathrm{~min}$, then baked at $200^{\circ} \mathrm{C}$ for $25 \mathrm{~min}$. The bread making tests were done with optimal water absorption estimated from a Farinograph (Blabender, Inc., Germany) at 500 BU. This method is a bread making test that is convenient and suitable in order to evaluate baking quality of the flour, because this method without the first fermentation can shorten the bread making time and the error of this test result is small due to little damage of dough in dividing and rounding process during this baking test. Domestic flours of poor baking quality, Hokushin and Haruyutaka with sprouting damage (Haruyutaka (SD)), were blended with Victoria INTA and Harunoakebono at ratios of 100\%: 0\%, 75\%: 25\%, 50\%: 50\%, and 0\%: $100 \%$. The reason carrying the blending test of Harunoakebono, strong flour, is to clarify remarkable improvement effect of baking quality by ES flour. The specific loaf volume (SLV) of the breads was measured by the rapeseed replacement method ${ }^{12}$. The sliced bread was copied to evaluate the crumb grain.

\section{Dough properties}

The current of mixer's motor during mixing dough were measured with a method of TAKATA et $a l^{13)}$. The mixing peak time was obtained from the 
time of peak of current chart. The breaking force and deformation of the dough was measured by using $10 \mathrm{~g}$ dough after bench time with a method of YAMAUCHI et al ${ }^{14}$. Three $10 \mathrm{~g}$ samples of dough were formed into $7 \mathrm{~cm} \times 2.5 \mathrm{~cm}$ after twice sheeting though $2.49 \mathrm{~mm}$ rolls, and then they were stretched at a speed of $5 \mathrm{~mm} / \mathrm{s}$ with a plunger $(\mathrm{p}-21)$ by REHONER (model RE 33005, Yamaden Co., Ltd., Tokyo). The breaking force and deformation were determined from the breaking point of dough. The total gassing powers at $30^{\circ} \mathrm{C}$ for 1 hour and 2 hours were measured with a Fermograph II (ATTO Co., Ltd., Tokyo) with $20 \mathrm{~g}$ of dough after bench time. The data shown are an average value of two samples. The data regarding vacuum expansion (gas retention) of dough was also measured by a method of YAMAUCHI $e t a l^{11}$,, which requires the use of $20 \mathrm{~g}$ dough following proofing. Gas retention was evaluated by measuring the maximum volume of dough in a cylinder under low pressure.

\section{Statistical analysis}

All data except of Tabs. 1 and 2, SV (Fig.3), and mixing peak time (Fig.4) were averaged to obtain mean values. The standard error of average was shown in Fig.. The result of SLV was evaluated by a analysis of variance using Dancan's multiple range test. By using the multiple-regressive analysis program of Excel '97, the multipleregressive equation and various correlation coefficients were obtained by using the data of SLV, protein content of flour, and breaking force of dough. SLV is a dependent variable, and protein content of flour and breaking force of dough are independent variables. The decision of appropriate and useful independent variable for estimating SLV was done like the following. The independent variables, protein content and breaking force of dough, were narrowed from five data measured in this study, protein content, SV, mixing peak time, breaking force of dough, and vacuum expansion of dough, with stepwise regression method of StatView software (SAS Institute Inc.).

\section{Results and Discussion}

\section{Properties of flours}

The characters of the flours used in this experiment are shown in Table 1. The Victoria INTA has a high protein content and SV, and the Farinograph characteristics were nearly equal to the $1 \mathrm{CW}$ and HRW. The protein content and SV of Harunoakebono were somewhat higher than that of $1 \mathrm{CW}$, and the Farinograph characteristics of the Harunoakebono were almost equal to those of $1 \mathrm{CW}$ and HRW except of the weakness. Hokushin showed a low protein content and a very low SV, and the Farinograph characteristics indicated very low water absorption, short development time, and large weakness. Haruyutaka (SD) only had a low maximum viscosity in the RVA as result of the sprouting damage that it had received before the harvest. The protein content of Haruyutaka (SD) was a little higher than that of the $1 \mathrm{CW}$. The SV of Haruyutaka (SD) was lower than that the $1 \mathrm{CW}$. In spite of the fact that the protein content of the Haruyutaka (SD) is considerable high, the SV was somewhat low value. As the reason, the sprouting damage seems to be the cause, as reported by Lukow et $a l^{15}$. In Farinograph characteristics, the Haruyutaka (SD) had considerably little water absorption and short development time, and a considerably large weakness. Though the results are not shown, the Farinograph characteristics of the blended flours obtained by mixing Hokushin and Haruyutaka (SD) with Victoria INTA and

Table 1 Properties of trial flours

\begin{tabular}{|c|c|c|c|c|c|c|}
\hline \multirow[b]{2}{*}{ Materials } & \multirow{2}{*}{$\begin{array}{c}\text { Flour } \\
\text { protein } \\
(\%)\end{array}$} & \multirow{2}{*}{$\begin{array}{l}\mathrm{sv}^{1)} \\
(\mathrm{m} \ell)\end{array}$} & \multirow{2}{*}{$\begin{array}{c}\mathrm{RVAPV}^{2)} \\
(\mathrm{RVU})\end{array}$} & \multicolumn{3}{|c|}{ Farinograph characteristics } \\
\hline & & & & $\begin{array}{l}\mathrm{Ab}^{3} \\
(\%)\end{array}$ & $\begin{array}{l}\mathrm{DT}^{4)} \\
(\mathrm{min})\end{array}$ & $\begin{array}{l}\mathrm{Wk}^{5)} \\
(\mathrm{BU})\end{array}$ \\
\hline $1 \mathrm{CW}$ & 12.7 & 36 & 250 & 66.0 & 11.8 & 15 \\
\hline HRW & 11.6 & 35 & 289 & 64.0 & 8.7 & 15 \\
\hline Hokushin & 11.3 & 9 & 277 & 58.5 & 4.0 & 90 \\
\hline Haruyutaka (SD) & 13.8 & 30 & 152 & 60.5 & 6.0 & 60 \\
\hline Victoria INTA & 15.0 & 69 & 235 & 65.5 & 10.7 & 20 \\
\hline Harunoakebono & 13.0 & 40 & 314 & 65.0 & 9.5 & 30 \\
\hline
\end{tabular}

1) SDS-sedimentation volume, 2) RVA peak viscosity, 3) Water absorption, 4) Development time, 5 ) Weakness 
Harunoakebono had reasonably medium properties compared to the flours of raw materials used the blended flour. In the case blended with ES flour, the characteristics of blended flours were drastically improved and were similar to those of $1 \mathrm{CW}$ and HRW controls.

\section{Dough properties of trial flour}

The mixing peak time, physical property (breaking force and deformation), total gassing power, and vacuum expansion (gas retention) of various doughs were shown in Table 2. The mixing peak time of the Victoria INTA was a lot longer than that of the $1 \mathrm{CW}$ and HRW because the Victoria INTA had very strong gluten. Harunoakebono, which has the strongest gluten among the domestic wheats, showed a peak time nearly equal to the $1 \mathrm{CW}$. The mixing peak time for Hokushin and Haruyutaka (SD) were each short and somewhat short, which showed that these flours have weaker gluten than those of $1 \mathrm{CW}$ and HRW. Victoria INTA, which has very strong gluten, showed a breaking force that was much higher than that of the controls, and Hokushin, on the contrary, had a breaking force that was quite low. The breaking forces of Harunoakebono and Haruyutaka (SD) were a little lower than that of the controls. The breaking deformation of Hokushin, Haruyutaka (SD), and Harunoakebono was rather larger than that of the HRW. Those of $1 \mathrm{CW}$ and Victoria INTA were respectively somewhat small and large in comparison of the HRW. Though the results are not shown, the breaking deformation of the blended flours had reasonably medium values compared to the flours of raw materials used the blended flour. The total gassing power of Hokushin was nearly equal to the HRW, and those of Haruyutaka (SD), Victoria INTA, and Harunoakebono showed somewhat lager value than the HRW, and that of $1 \mathrm{CW}$ was somewhat smaller than the HRW.
Though the results are not shown, the total gassing powers of the blended flours were not largely different compared with the HRW. The vacuum expansion of Victoria INTA was much higher than that of the controls. The value of Harunoakebono was nearly equal to that of the controls. The value was somewhat low on the Hokushin. The value of Haruyutaka (SD) was a little higher value than that of the controls.

\section{Bread making quality of flours blended with Victoria INTA and Harunoakebono}

The SLV of breads made from various blended flours is shown in Fig.1 and Table 3. The results of crumb grains of the breads are shown in Fig.2. The SLV of Hokushin was considerable low, and the crumb grain, bread aspect, and handling properties of dough were not good. The SLV of Haruyutaka (SD) showed equivalent value to controls, since the protein content was considerably high. However, the crumb grain, bread aspect, and handling properties

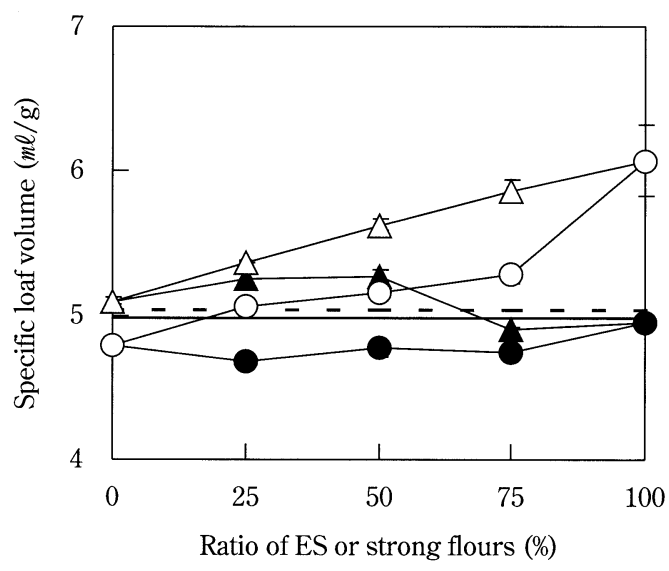

Fig. 1 SLV of breads made from blended flours

Symbols show each flour :-, $1 \mathrm{CW} ;---$, HRW ;

-○-, Hokushin : Victoria INTA ;--, Hokushin : Harunoakebono : $\smile$, Haruyutaka (SD) : Victoria INTA ; $-\mathbf{-}$, Haruyutaka (SD) : Harunoakebono.

Symbol (I) shows standard error of average. ES and strong flour of horizontal axis show each Victoria INTA and Harunoakebono.

Table 2 Dough properties of trial flours

\begin{tabular}{|c|c|c|c|c|c|c|}
\hline \multirow[t]{2}{*}{ Materials } & \multirow{2}{*}{$\begin{array}{c}\text { Mixing peak time } \\
(\min )\end{array}$} & \multirow{2}{*}{$\begin{array}{l}\text { Breaking force } \\
(\mathrm{N})\end{array}$} & \multirow{2}{*}{$\begin{array}{l}\text { Breaking deformation } \\
(\mathrm{mm})\end{array}$} & \multicolumn{2}{|c|}{$\begin{array}{c}\text { Total gassing power } \\
(\mathrm{m} \ell)\end{array}$} & \multirow{2}{*}{$\begin{array}{l}\text { Vacuum expansion } \\
(\mathrm{m} \ell)\end{array}$} \\
\hline & & & & $1 \mathrm{~h}$ & $2 \mathrm{~h}$ & \\
\hline $1 \mathrm{CW}$ & 2.4 & 3.04 & 38.0 & 29.8 & 68.4 & 120 \\
\hline HRW & 2.7 & 2.63 & 46.0 & 30.5 & 71.3 & 118 \\
\hline Hokushin & 1.6 & 1.78 & 72.7 & 29.9 & 70.6 & 112 \\
\hline Haruyutaka (SD) & 2.1 & 2.24 & 66.7 & 31.4 & 73.0 & 123 \\
\hline Victoria INTA & 4.3 & 4.42 & 56.8 & 30.4 & 72.0 & 152 \\
\hline Harunoakebono & 2.2 & 2.41 & 70.3 & 30.7 & 72.1 & 115 \\
\hline
\end{tabular}


Table 3 Specific loaf volume of breads made from blended flours

\begin{tabular}{|c|c|c|}
\hline $\begin{array}{l}\text { Materials } \\
\text { Ratio of ES or S flours }\end{array}$ & $\begin{array}{c}\mathrm{SLV}^{1)}(\mathrm{m} \ell / \mathrm{g}) \\
\text { Hokushin : } \mathrm{ES}^{2)} \text { or } \mathrm{S}^{3)} \text { flours }\end{array}$ & $\begin{array}{c}\mathrm{SLV}^{1)}(\mathrm{m} \ell / \mathrm{g}) \\
\text { Haruyutaka }(\mathrm{SD}): \mathrm{ES}^{2)} \text { or } \mathrm{S}^{3)} \text { flours }\end{array}$ \\
\hline $1 \mathrm{CW}$ & 4.98 & 4.98 \\
\hline HRW & 5.04 & 5.04 \\
\hline Domestic flour $100 \%$ & 4.79 & 5.10 \\
\hline ES flour $25 \%$ & $5.07^{*}$ & 5.37 \\
\hline ES flour $50 \%$ & $5.16^{*}$ & $5.62^{* * *}$ \\
\hline ES flour $75 \%$ & $5.28^{* * *}$ & $5.86^{* * *}$ \\
\hline ES flour $100 \%$ & $6.07^{* * *}$ & $6.07^{* * *}$ \\
\hline S flour $25 \%$ & 4.69 & 5.26 \\
\hline S flour $50 \%$ & 4.77 & 5.27 \\
\hline S flour $75 \%$ & 4.75 & 4.90 \\
\hline $\mathrm{S}$ flour $100 \%$ & 4.95 & 4.95 \\
\hline
\end{tabular}

1) SLV, specific loaf volume ; 2) ES, extra strong ; 3 ) S, strong. * are significantly different from domestic flour $100 \%$ (Hokushin or Haruyutaka (SD)) at $\mathrm{p}<0.05,0.005$ in Duncan's multiple range test, respectively.

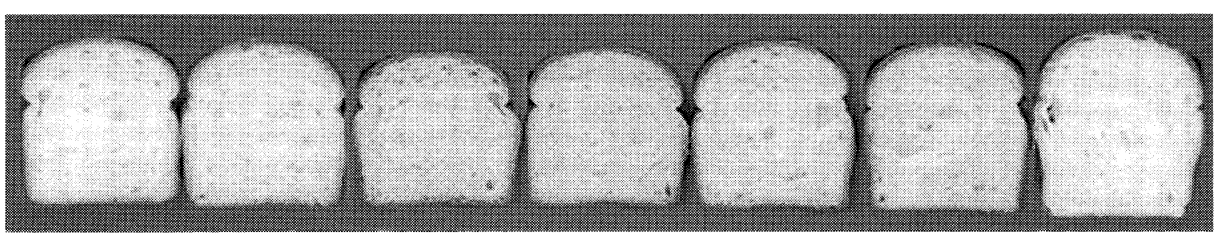

$1 \mathrm{CW} \quad$ HRW Hokushin100\% Hokushin75\% Hokushin50\% Hokushin25\% Victoria INTA100\% VictoriaINTA25\% VictoriaINTA50\% VictoriaINTA75\%

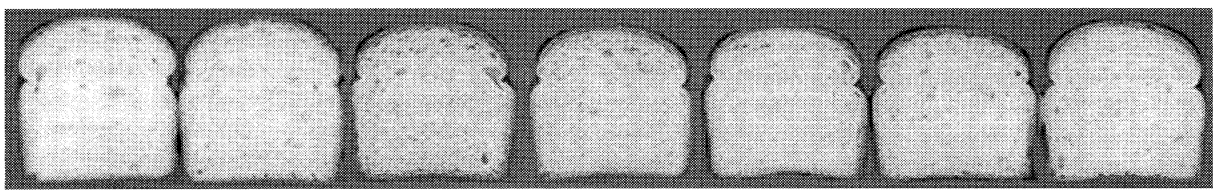

$1 \mathrm{CW} \quad$ HRW Hokushin100\% Hokushin75\% Hokushin50\% Hokushin25\% Harunoakebono100\% Harunoakebono $25 \%$ Harunoakebono50\% Harunoakebono $75 \%$

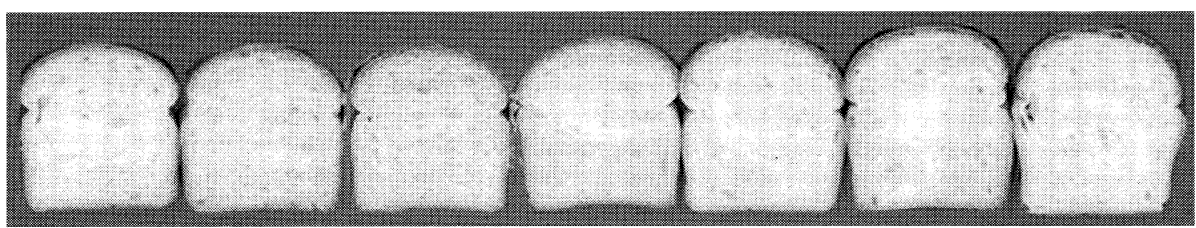

$1 \mathrm{CW} \quad \mathrm{HRW} \quad$ Haruyutaka(SD) $100 \%$ Haruyutaka(SD) $75 \%$ Haruyutaka(SD) $50 \%$ Haruyutaka(SD) $25 \%$ Victoria INTA100\% VictoriaINTA25\% VictoriaINTA50\% VictoriaINTA75\%

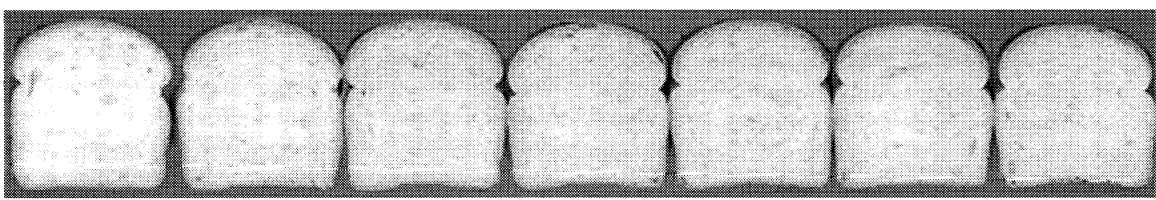

$1 \mathrm{CW} \quad \mathrm{HRW}$ Haruyutaka (SD) 100\% Haruyutaka(SD) 75\% Haruyutaka(SD) $50 \%$ Haruyutaka(SD) 25\% Harunoakebono100\% Harunoakebono25\% Harunoakebono50\% Harunoakebono75\%

Fig. 2 Crumb grain of breads made from blended flours 
of dough were not so good. When Victoria INTA was blended with Hokushin and Haruyutaka (SD), the SLV, crumb grains, and aspect of the breads were improved. When the ES ratio of blend mixed ES with Hokushin and Haruyutaka (SD) exceeded each $50 \%$ and $25 \%$, the quality of the breads from both blended flours, the total evaluation of SLV, crumb grain, and aspect of the bread, was equivalent to or better than the $1 \mathrm{CW}$ and HRW. It seemed that these breads from ES blend exceeded $25 \%$ was acceptable quality for consumer and there may be no substantial problem by using these domestic flours blend for bread making. While, when Harunoakebono was blended with both flours, the improvements of bread making quality of both blending flours were insignificant.

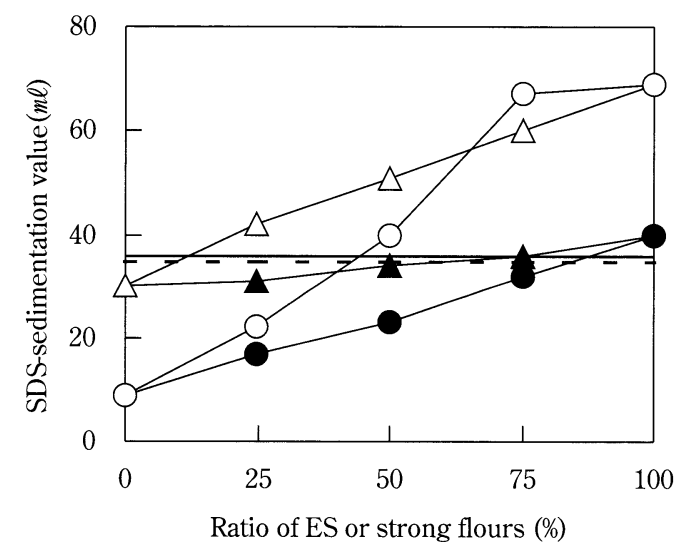

Fig. 3 SDS-sedimentation value of blended flours

Symbols are shown in Fig.1. ES and strong flour of horizontal axis show each Victoria INTA and Harunoakebono.

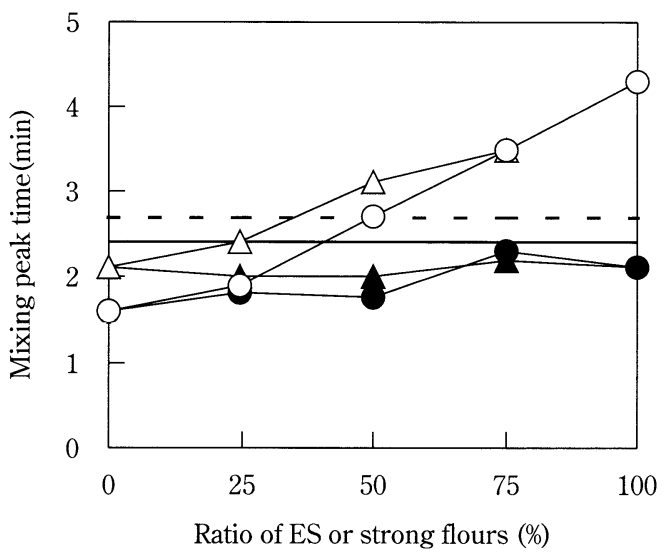

Fig. 4 Mixing peak time of doughs made from blended flours

Symbols are shown in Fig.1. ES and strong flour of horizontal axis show each Victoria INTA and Harunoakebono.

\section{Various properties of the blended flour and dough}

The various properties of the blended flour and dough except of protein content, SV, mixing peak time, breaking force, and vacuum expansion (gas retention) of dough, are shown in Figs. 3, 4, 5, and 6 . The protein content of the various blends was dependent on the protein content of the blended material flours (the data not shown). The SV of various blends changed according to the materials that were used in the blends. The SV of the blended flours increased drastically, as shown in Fig.3, and especially in the case of the Victoria INTA blend. When Victoria INTA was blended, the mixing peak time lengthened significantly as shown in Fig.4, and the blended flour with $50 \%$ of Victoria

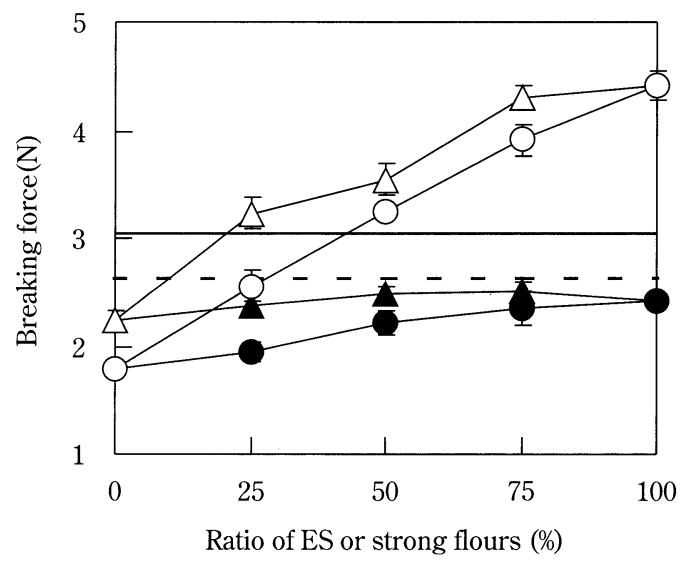

Fig. 5 Breaking force of doughs made from blended flours Symbols are shown in Fig.1. Symbol ( I ) shows standard error of average. ES and strong flour of horizontal axis show each Victoria INTA and Harunoakebono.

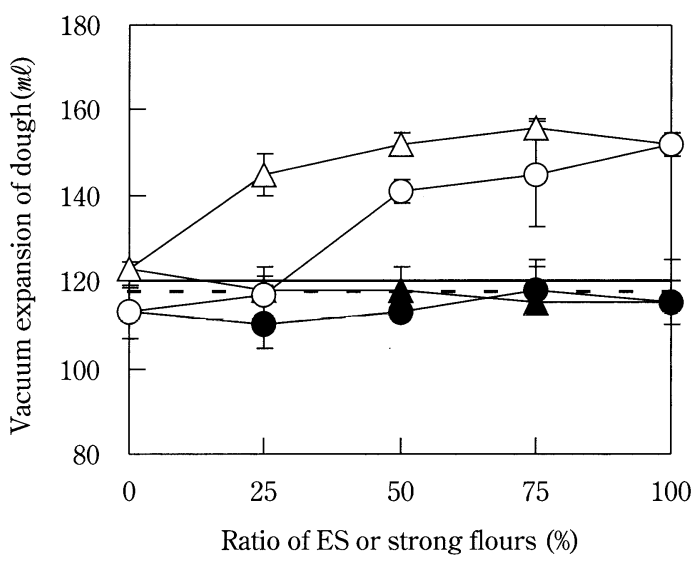

Fig.6 Vacuum expansion (gas retention) of doughs made from blended flours

Symbols are shown in Fig.1. Symbol ( I ) shows standard error of average. ES and strong flour of horizontal axis show each Victoria INTA and Harunoakebono. 
INTA showed an equivalent or greater value of mixing peak time compared to the $1 \mathrm{CW}$ and $\mathrm{HRW}$. However, when Harunoakebono was blended, the change in the mixing peak time was hardly noticeable. When Victoria INTA was blended, the breaking force of the dough grew sharply, as shown in Fig.5, as the proportion of the blend increased. However, when Harunoakebono was blended it was almost no change. In a blend with Victoria INTA, the vacuum expansion (gas retention) of dough was improved remarkably, and the improvement caused by blending ES flour was especially large when ES flour was blended with the Haruyutaka (SD) as shown in Fig.6. However, when Harunoakebono was blended, the improvements were insignificant in both cases.

From the above results, though the bread making quality of Hokushin (middle-strong flour) and Haruyutaka (SD) were seldom improved by blending with Harunoakebono, the strong flour, the properties of the two poor domestic flours improved and became similar or superior to foreign strong flour when they were blended with Victoria INTA. Furthermore, when the poorer domestic flours are blended and used for bread production, a suitable amount of ES flour added to the domestic flour seems to be the key on effective blend.

\section{Analysis of the improvements in breads made from the blended flours}

In general, SLV is an index for the quality of bread. It is greatly affected by the protein content of flour and the physical properties of the $\operatorname{dough}^{16) \sim 20)}$. Then, the reasonable equation which estimates SLV from protein content of flour and breaking force of dough was obtained with stepwise regression method and multiple-regressive analysis. The result is shown by the following.

\section{[Multiple-regressive equation]}

$$
\begin{aligned}
& \mathrm{X}_{1}=0.157 \cdot \mathrm{X}_{2}+0.251 \cdot \mathrm{X}_{3}+2.38 \cdots \cdots \cdots \\
& \mathrm{R}=0.914, \mathrm{R}^{2}=0.835, \mathrm{n}=17, \mathrm{r}_{12.3}=0.559, \\
& \mathrm{r}_{13.2}=0.611, \mathrm{r}_{23.1}=0.179
\end{aligned}
$$

$\mathrm{X}_{1}$, specific loaf volume $(\mathrm{m} \ell / \mathrm{g}) ; \mathrm{X}_{2}$, protein content of flour $(\%) ; \mathrm{X}_{3}$ : breaking force of dough (N) ; R,multiple correlation coefficient; $\mathrm{R}^{2}$, decisive rate of multiple correlation ; $\mathrm{n}$, data number; $r_{12.3}$, partial correlation coefficient between specific loaf volume and protein content; $\mathrm{r}_{13.2}$, partial correlation coefficient between specific loaf volume and breaking force; $r_{23.1}$, partial correlation coefficient between protein content and breaking force

These equation and coefficients were obtained by using the data $(n=17)$ obtained from the bread making tests described above. The values of the multiple correlation coefficients and the decisive rate of multiple correlation showed high 0.914 and 0.835 , respectively, and the multiple correlation coefficient of 0.914 was significant at a $0.1 \%$ level. The partial correlation coefficients, $r_{12.3}$ and $r_{13.2}$, were greater than that of $r_{23.1}$. The value between the protein content and the breaking force, $r_{23.1}$, was very low and the protein content did not almost correlate with the breaking force. From these results, protein content and breaking force are suitable as independent variable to estimate the SLV and this equation (1) seems to be useful as an equation that estimates the SLV from two independent variables.

Subsequently, by assuming that the protein content of Haruyutaka (SD) and Harunoakebono is equal to that of Hokushin and Victoria INTA and that breaking force of each dough shows experimental data, the SLV of the each blended flours was calculated by the equation (1) given above. By above assumption, it becomes possible that the improvement effect of bread making quality by Harunoakebono and Victoria INTA is compared at identical protein content. The result is shown in Fig.7. It was proven that the improvements in the SLV that were obtained by

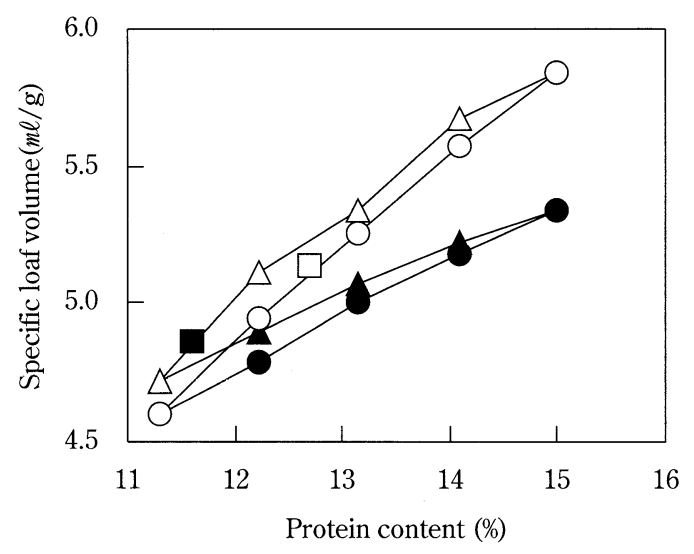

Fig. 7 Calculated results of SLV on breads from blended flours

Symbols show each flour : $\square, 1 \mathrm{CW}$; $\square$, HRW ;

$-\bigcirc$, Hokushin : Victoria INTA ;--, Hokushin : Harunoakebono ;

$\triangle$, Haruyutaka (SD) : Victoria INTA ; - , Haruyutaka (SD) :

Harunoakebono. 
blending Victoria INTA were great in comparison with those of Harunoakebono, even if they were compared in blended flours with an equivalent protein content that could neglect the effect of the protein content known to influence the SLV ${ }^{19), 20)}$. From these results, the improvements in the breaking force of dough that are the result of blending Victoria INTA seem to greatly influence the improvement of the SLV in the domestic flours that have poor quality when used for baking.

The changes of SLV, each contribution of increase of protein content and breaking force for SLV by blending Victoria INTA and Harunoakebono with Hokushin and Haruyutaka (SD) were calculated by using the above equation ( 1 ). The calculated results were obtained by placing in above equation the values of protein content and breaking force of the dough that were obtained in the experiment. The calculated results and actual changes of SLV were shown in Table 4 . Table 4 proves that the main factor for improvement of SLV on bread making in case of a blend of Victoria INTA was an increase in the breaking force of the dough. Especially, when Victoria INTA was blended to Haruyutaka (SD), the contribution ratio of breaking force of the dough on the progress of the SLV was big. Because, as the protein content of Haruyutaka (SD) was rather high, the protein contents of the flour blended Victoria INTA did not increase too greatly. As the calculated changes in the SLV more or less agreed with those from the actual bread making results, the calculated results of the causes of the improvements based upon each independent variable in the equation (1) given above seem to be almost appropriate.
From the above results, the ES flour has a gluten that forms a strong dough structure as speculated from a very large breaking force of the dough of an ES flour such as Victoria INTA. Therefore, using blends with ES flour contributed more to improving the baking quality of flours than using ordinary strong flour. In other words, ES flours have the characteristics to carry poor domestic flours to better strong flour with good baking quality than ordinary strong flour. This characteristics with ES flour seems to be related to the particular physical properties.

\section{Conclusions}

The bread making quality of two unsuitable domestic flours for bread production in Japan, Hokushin and Haruyutaka (SD), was improved by blending with Victoria INTA, an ES flour. The improvements of bread making quality by blending poor domestic flours with ES flour were principally due to the progress of physical property of the dough. This new blending technology will be useful to improve the poor bread making quality of Japanese flours effectively.

Acknowledgment This work was supported in part by Research and Development Program for New Bio-industry Initiatives of Bio-oriented Technology Research Advancement Institution.

\section{References}

1 ) Ichinose, Y., Takata, K., Kuwabara, T., Iriki, N., ABiko, T. and Yamauchi, H.: Efects of increase in $\alpha$-amylase and endo-protease activities during germination on the bread making quality of wheat,

Table 4 Contribution of protein content and breaking force on improvement of specific loaf volume

\begin{tabular}{|c|c|c|c|c|}
\hline Materials & $\begin{array}{c}\text { Change of SLV }{ }^{1)} \\
\text { (calculation) } \\
(\mathrm{m} \ell / \mathrm{g})\end{array}$ & $\begin{array}{c}\text { Contribution of } \mathrm{PC}^{2)} \\
\text { (calculation) } \\
(\mathrm{m} / \mathrm{g})\end{array}$ & $\begin{array}{c}\text { Contribution of } \mathrm{BF}^{3)} \\
\text { (calculation) } \\
(\mathrm{m} \ell / \mathrm{g})\end{array}$ & $\begin{array}{c}\text { Change of } \mathrm{SLV}^{11} \\
\text { (experiment) } \\
(\mathrm{m} \ell / \mathrm{g})\end{array}$ \\
\hline $\begin{array}{l}\text { Hokushin } 50 \%: \\
\text { Victoria INTA } 50 \%\end{array}$ & 0.657 & 0.291 & 0.366 & 0.370 \\
\hline $\begin{array}{l}\text { Hokushin } 50 \% \text { : } \\
\text { Harunoakebono } 50 \%\end{array}$ & 0.244 & 0.134 & 0.110 & -0.020 \\
\hline $\begin{array}{l}\text { Haruyutaka (SD) } 50 \% \text { : } \\
\text { Victoria INTA } 50 \%\end{array}$ & 0.423 & 0.094 & 0.329 & 0.520 \\
\hline $\begin{array}{l}\text { Haruyutaka (SD) } 50 \%: \\
\text { Harunoakebono } 50 \%\end{array}$ & -0.003 & -0.063 & 0.060 & 0.170 \\
\hline
\end{tabular}

1) SLV, specific loaf volume ; 2) PC, protein content ; 3) BF, beraking force

Change of SLV (calculation), and Contribution of PC and BF (calculation)were calculated by using equation(1).

Change of SLV (experiment) was obtained from experimental data in Fig. 1. 
Food Sci. Technol. Res., 7, 214 219 (2001)

2 ) Takata, K., Yamauchi, H., IRIKI, N., Ichinose, Y. and Kuwabara, T. : Effect of blending soft and hard wheat flour on bread making quality, Proceeding of the ninth assembly of the wheat breeding society of Australia, 241 242 (1999)

3 ) Yamauchi, H., Nishio, Z., Takata, K., Oda, Y., Yamaki, K., Ishida, N. and Miura, H.: The breadmaking of a domestic flour blended with an extra strong flour and staling of the bread made from the blended flour, Food Sci. Technol. Res., 7, 120 125 (2001)

4) Yamauchi, H., Takata, K. and Yamaki, K.: The new application technology of extra strong wheat flour to breads and noodles, Shokuhinkogyo, 43, 31 〜38 (1999)

5 ) Bushuk, W.: The baking potential of Glenlea wheat, Can. J. Plant Sci., 60, 737 739 (1980)

6 ) Morris, C. F.: Impact of bleeding hard and soft white wheats on milling and baking quality, Cereal Foods World, 37, 643 648 (1992)

7 ) Takata, K., Yamauchi, H., Iriki, N. and KUwABARA, T.: Prediction of bread making quality based by prolonged swelling SDS-sedimentation test, Breeding Sci., 49, 221 223 (1999)

8 ) Axford, D. W. E., McDermott, E. E. and Redman, D. G.: Note on the sodium dodecyl sulfate test of bread making quality ; Comparison with Pelshenke and Zeleny tests, Cereal Chem., 56, 582 〜 584 (1979)

9 ) American Association of Cereal Chemists : Approved Methods of the AACC, Method 08-01, The Association, St. Paul, MN (1991)

10) Watanabe, H. and Suzuki, O.: Rapid method for determining viscosity breakdown of wheat flour using rapid visco-analyzer, Nihon Shokuhin Kogyo Gakkaishi., 38, 44〜48 (1991)

11) Yamauchi, H., Ichinose, Y., Takata, K., Iriki, N. and KuwABARA, T.: Simple estimation of bread making quality of wheat flour by modified expansion test under reduced pressure, Nihon Shokuhin Kagaku Kogaku Kaishi., 47, 46 49 (2000)

12) Yamauchi, H., Fujimura, M., Ohyo, K., Hirakawa, T. and KoBAyAshI, T.: Role of shortening and monoglyceride on staling of white bread made by straight dough method, Nihon Shokuhin Kogyo Gakkaishi., 39, 383 390 (1992)

13) Takata, K., Yamauchi, H., Iriki, N. and KuwABARA, T.: Relationship between seed storage protein and bread making quality of bread wheat cultivar Haruyutaka, Ikushugaku Kenkyu., 2, 11 16 (2000)

14) Yamauchi, H., Takata, K. and Kuwabara, T.: The small scale method to measure physical properties of dough for simple bread making evaluation of flours, Nihon Shokuhin Kagaku Kogaku Kaishi, 48, 138 141 (2001)

15) Lukow, O.M. and Bushuk, W.: Influence of germination on wheat quality. I. Functional (breadmaking) and Biochemical Properties, Cereal Chem., 61, 336 339 (1984)

16) $\mathrm{He}, \mathrm{H}$. and Hoseney, R. C.: Effect of the quantity of wheat flour protein on bread loaf volume, Cereal Chem., 69, 17〜19 (1992)

17) Janssen, A. M., Vliet, T. van and Vereijken, M. : Fundamental and empirical rheological behavior of wheat flour doughs and comparison with bread making performance, J. Cereal Sci., 23, 43 54 (1996)

18) Janssen, A. M., Vliet, T. van and Vereijken, M. : Rheological behavior of wheat glutens at small and large deformations. Comparison of two glutens differing in bread making potential, $J$. Cereal Sci., 23, 19 31 (1996)

19) Tipples, K. H. and KilboRn, R. H. : "Baking strength index" and the relation of protein content of loaf volume, Can. J. Plant Sci., 54, 231 234 (1974)

20) Weegels, P. L., Hamer, R. J. and Schofield, J. D. : Critical review functional properties of wheat glutenin, J. Cereal Sci., 23, $1 \sim 18$ (1996)

\section{超強力粉ブレンドによる 国産小麦粉の製パン性の改善}

山内宏昭 ${ }^{* 1} \cdot$ 野田高弘 ${ }^{* 1} \cdot$ 松浦 (遠藤) 千絵*1

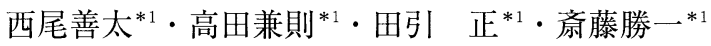
小田有二*1 . 船附稚子 ${ }^{* 2} \cdot$ 入来規雄 ${ }^{* 2}$

* 1 農業技術研究機構

北海道農業研究センター畑作研究部

（０82-0071北海道河西郡芽室町新生）

* 2 農業技術研究機構

北海道農業研究センター地域基盤研究部

（テ062-8555 札幌市豊平区羊ヶ丘 1 番地）

超強力粉のVictoria INTAと強力粉の春のあけぼのを ブレンドした 2 種類の国産小麦粉（ホクシン，ハルユタ カ）の製パン性が試験された。製パンに適さない国産小 麦粉であるホクシン (代表的日本の中力粉), ハルユ夕 カ（発芽被害を受けた準強力粉）の製パン性は，Victoria 
INTAをブレンドすることによって改善された。その結 果は以下のとおりであった。(1) 適当量の超強力粉を用 いることによって，低製パン性の国産小麦粉は改質され， パン用の外国産小麦粉が一般的にもっている製パン特性 が付与された。(2)本実験のブレンド粉から製造された パンの比容積の推定は, 以下の重回帰式によって可能で あった。 $\mathrm{X}_{1}=0.157 \mathrm{X}_{2}+0.251 \mathrm{X}_{3}+2.38 （ \mathrm{X}_{1}$ : 比容積 $(\mathrm{m} \ell / \mathrm{g}), \mathrm{X}_{2}$ : 小麦粉のタンパク質含量 $(\%), \mathrm{X}_{3}$ : 生 地の破断力 $(\mathrm{N}))$ 。 (3)この式を用いた解析によって，超 強力粉ブレンドによる低製パン性国産小麦粉の製パン性 改善の主要因が，生地物性の改善（生地破断力）の向上 であることが明らかになった。

(平成15年 3 月 5 日受付, 平成 15 年 5 月 19 日受理) 